University for Business and Technology in Kosovo

UBT Knowledge Center

UBT International Conference

2015 UBT International Conference

Nov 7th, 9:00 AM - 5:00 PM

\title{
Effect of Steel Fiber and Polypropylene Fiber on Reinforced Concrete
}

\author{
Erjola Reufi \\ University of Tirana, reufierjola@gmail.com \\ Jozefita Marku \\ University of Tirana, markujoz@yahoo.com
}

Follow this and additional works at: https://knowledgecenter.ubt-uni.net/conference

Part of the Civil Engineering Commons, and the Structural Engineering Commons

\section{Recommended Citation}

Reufi, Erjola and Marku, Jozefita, "Effect of Steel Fiber and Polypropylene Fiber on Reinforced Concrete" (2015). UBT International Conference. 67.

https://knowledgecenter.ubt-uni.net/conference/2015/all-events/67

This Event is brought to you for free and open access by the Publication and Journals at UBT Knowledge Center. It has been accepted for inclusion in UBT International Conference by an authorized administrator of UBT Knowledge Center. For more information, please contact knowledge.center@ubt-uni.net. 


\title{
Effect of Steel Fiber and Polypropylene Fiber on Reinforced Concrete
}

\author{
Erjola Reufi ${ }^{1}$, Jozefita Marku ${ }^{2}$ \\ ${ }^{1,2}$ Universiteti i Tiranës, Fakulteti i Shkencave të Natyrës,Departamenti Kimi Industriale \\ markujoz@yahoo.com¹, reufierjola@gmail.com²
}

\begin{abstract}
This paper presents the results of an experimental study that investigated, the effects of steel fibers and poly propylene fibers on the mechanical properties of concrete.

Two types of fibers used are hooked end steel fibers of $50 \mathrm{~mm}$ and $30 \mathrm{~mm}$ length with the aspect ratio of 67 (length $50 \mathrm{~mm}$ and diameter $0.75 \mathrm{~mm}$ ) and 44 (length $30 \mathrm{~mm}$ and diameter $0.75 \mathrm{~mm}$ ). On the other hand, three types of poly propylene fibers are used of length $12 \mathrm{~mm}, 6 \mathrm{~mm}$ and $3 \mathrm{~mm}$. Steel fibers are used of $0 \%, 0.25 \%, 0.5 \%$, and $1 \%$ by the volume of concrete and poly propylene fiber are prepared of $0 \%, 0.25 \%, 0.5 \%, 1 \%$ by the weight of cement.

The experimental program consisted of testing the compressive strength and split tensile strength on steel fiber- reinforced concrete and poly propylene fiber-reinforced concrete.

28 day compressive and split tensile strength ëere prepared and tested by using cubes of dimensions

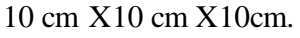

Keywords: Aspect Ratio, Steel Fiber, Polypropy lene Fiber, Poly propylene Fiber-Reinforced

\section{Introduction}

Fiber reinforced concrete (FRC) is a composite material consisting of cement, sand, coarse aggregate, water and fibers. In this composite material, short discrete fibers are randomly distrubuted throughout the concrete mass. The behavioral efficiency of this composite material is far superior to that of plain concrete and many ohter construction materails of equal cost. [1], [12]

Due to this benifit, the use of FRC (Fiber Reinforced Concrete) has steadily increased during the last two decades and its current field of application includes : airport and

highway pavement, earthquake resistant and explosive resistant structures mine and tunnel linings, bredge deck etc.[2]

Review of work done by various researcher discuss the mechanism of fiber matrix interaction where various models are used to compute the bonding between the fibers and cement matrix.as the bonding of fiber and the matrix plays a major role in the composite behavior.[3],[13]

The randomly distributed short fibers are generally introduced into concrete to enhance its control crack system and mechanical properties such as toughness, impact resistance, ductility. Properties of fibers based concrete changes with varying concrete fiber materials geometry distribution, orientation and densities. [4]

When fibers is added to a concrete mix each and every individual fiber receives a coating of cement paste. This increasing bonding with cement matrices and minimized chemical reaction between fibers and cement matrices. [5]

The evaporation of concrete surfaces water is factor in creating the contract paste fracture in concrete which leads with to the formation of stress since the concrete starts to strengthness. [6]

The split tensile strength of all fibrous composite matrices was significantly higher than that of plain concrete. This is because in fibrous matrix when it cracks cause the load to be transferred from the cementitious at the crack interface.[7] 


\section{Materials and mix proportions}

\subsection{Materials}

The cement used in concrete mixtures was ordinary Portland cement of 32.5 grade. Fine aggregate and coarse aggregate of river of Milot with maximum size of $25 \mathrm{~mm}$ are used. Natural river sand from Milot river is used with maximum size of $5 \mathrm{~mm}$. Two types of fibers were used for present investigation as shown in figure 2 hooked steel fibers - 50mm and $30 \mathrm{~mm}$ long and figure 1 polypropylene fibers with $12 \mathrm{~mm}, 6 \mathrm{~mm}$ and $3 \mathrm{~mm}$ length.

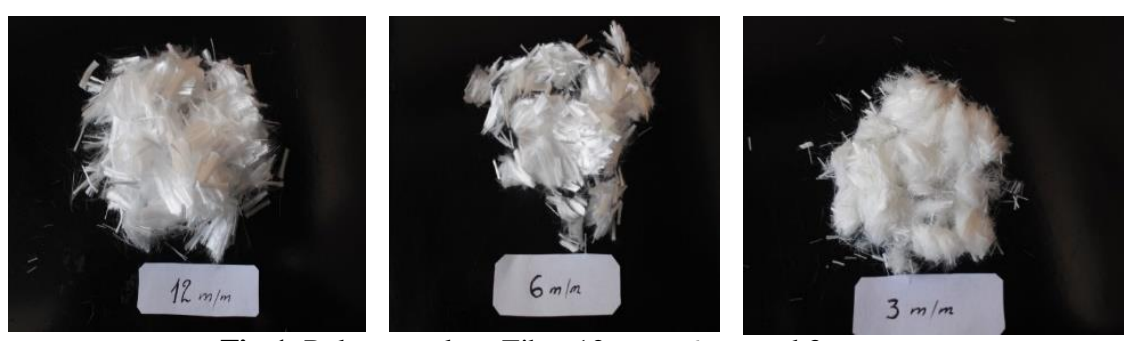

Fig 1. Poly propy lene Fiber $12 \mathrm{~mm}, 6 \mathrm{~mm}$ and $3 \mathrm{~mm}$
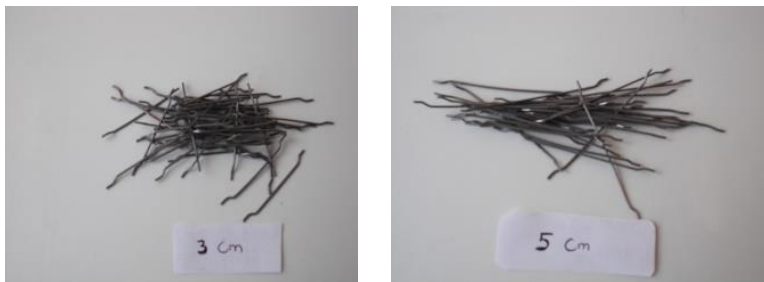

Fig 2. Steel Fiber $3 \mathrm{~cm}$ and $5 \mathrm{~cm}$

\subsection{Mix Design}

Mix design was done as per ASTM C 1116-91. The super plasticizer dosage was adopted as $0.25 \%$ by the weight of cement [9]

Table 1: Mix design of concrete

\begin{tabular}{|c|c|c|}
\hline Mix proportion & Specifc gravity $\left(\mathrm{kg} / \mathrm{m}^{3}\right)$ & Ratio \\
\hline Sand & 900 & \\
\hline Cement & 400 & Water: Cement 0.5 \\
\hline $\begin{array}{l}\text { Coarse Aggregate } 10-25 \\
\mathrm{~mm}\end{array}$ & 670 & \\
\hline $\begin{array}{lll}\text { Coarse Aggregate } 5-10 \\
\mathrm{~mm}\end{array}$ & 300 & Aggregate: Cement 2.67 \\
\hline Water & 200 & \\
\hline Super plasticizer & 1 & $\begin{array}{c}\text { Superplasticizer } 0.25 \% \text { by } \\
\text { the weight of cement }\end{array}$ \\
\hline $\begin{array}{l}\text { Steel Fiber } \\
\mathrm{SF} 1=5 \mathrm{~cm} \\
\mathrm{SF} 2=3 \mathrm{~cm}\end{array}$ & & $\begin{array}{l}0.25 \%, 0.5 \%, 1 \% \text { by } \\
\text { the volume of concrete }\end{array}$ \\
\hline $\begin{array}{l}\text { Polypropylene Fiber } \\
\text { PP1 }=12 \mathrm{~mm} \\
\text { PP2 }=6 \mathrm{~mm} \\
\text { PP3 }=3 \mathrm{~mm}\end{array}$ & & $\begin{array}{c}0.25 \%, 0.5 \% 1 \% \text { by the } \\
\text { weight of cement }\end{array}$ \\
\hline
\end{tabular}




\subsection{Preparations and curing of test samples}

The preparation of all test samples was prepared in a 501 concrete mixer. The mixing procedure was used is : dry mixing of aggregate in mixer $0.5 \mathrm{~min}$, dry mixing of cement and aggregate in mixer 0.5 min addition of water, mixing for $3 \mathrm{~min}$, addition of superplasticizer and then fiber, mixing by mixer for 2.5 up to $3.5 \mathrm{~min}$ [8], [10], [11].

Compressive Strength

Compression test were carried out at the age of 28 day, on cubic specimens (100x100x100 mm) Test were done using a hydraulic press. The specimens were centered on the tray of the pres s then a continuous load was applied on the specimen.

The ultimate compression load for each plain concrete and fiber reinforced concrete specimen were recorded.

Split Tensile strength

Flexural Strength test at the age of 28 days were performed on plain and fiber reinforced concrete cubic specimens $(100 \times 100 \times 100 \mathrm{~mm}) \ldots$

\section{Result and conclusion}

Below are represented the result of compressive and split tensile strength of steel and poly propy lene reinforced concrete

Table 2 : Results of Compressive Strength of Steel Reinforced Concrete

\begin{tabular}{|c|c|c|c|c|}
\hline Type of fibers & $\begin{array}{l}\text { Compressive } \\
\text { Strength } \\
\text { N/mm² } \\
0 \% \text { Steel Fiber }\end{array}$ & $\begin{array}{l}\text { Compressive } \\
\text { Strength } \\
\mathrm{N} / \mathrm{mm}^{2} \\
0.25 \% \quad \text { steel } \\
\text { fiber }\end{array}$ & $\begin{array}{l}\text { Compressive } \\
\text { Strength } \\
\mathrm{N} / \mathrm{mm}^{2} \\
0.5 \% \quad \text { Steel } \\
\text { fiber }\end{array}$ & $\begin{array}{l}\text { Compressive } \\
\text { Strength } \\
\mathrm{N} / \mathrm{mm}^{2} \\
1 \% \text { Steel Fiber }\end{array}$ \\
\hline $\begin{array}{l}\text { SF1 } \\
\text { Steel Fiber } \\
5 \mathrm{~cm}\end{array}$ & 29.52 & 30.4 & 32.7 & 33.5 \\
\hline $\begin{array}{l}\text { SF2 } \\
\text { Steel Fiber } \\
3 \mathrm{~cm} \\
\end{array}$ & 29.5 & 29.52 & 33.5 & 34.7 \\
\hline
\end{tabular}

Table 3 : Result of tensile Strength of Steel Reinforced Concrete

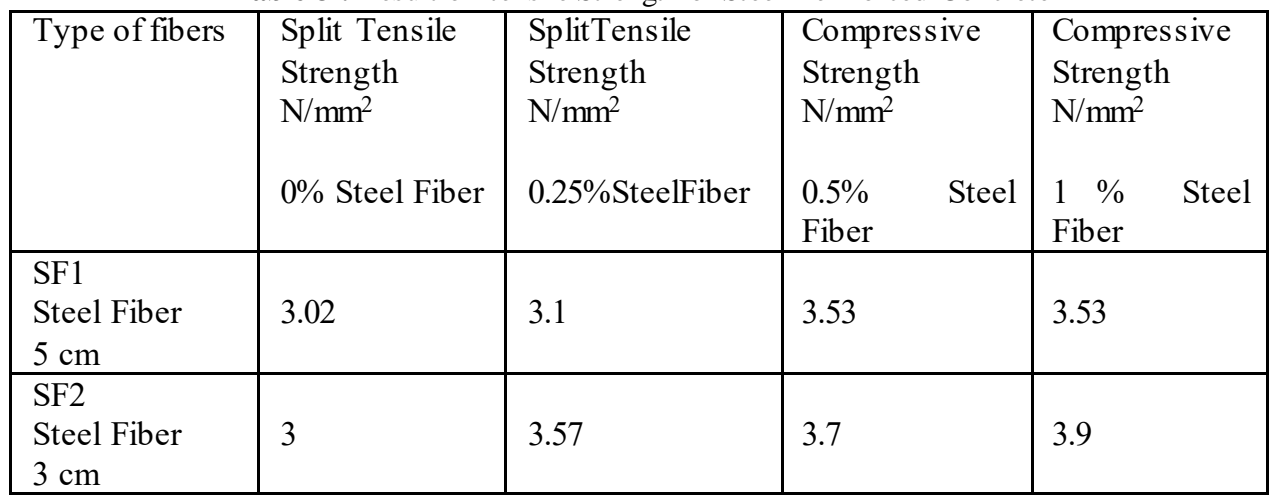


International Conference on Civil Engineering, Infrastructure and Environment, Nov 2015

Table 4: Results of Compressive Strength of Poly propylene Reinforced Concrete

\begin{tabular}{|c|c|c|c|c|}
\hline Type of PP fiber & $\begin{array}{l}\text { Compressive } \\
\text { Strength N/mm } 2 \\
0 \% \\
\text { polypropylene } \\
\text { fiber }\end{array}$ & $\begin{array}{l}\text { Compressive } \\
\text { Strength N/mm } \\
\\
0.25 \% \\
\text { poly propylene } \\
\text { fiber }\end{array}$ & $\begin{array}{l}\text { Compressive } \\
\text { Strength N/mm }{ }^{2} \\
0.5 \% \\
\text { polypropylene } \\
\text { fiber }\end{array}$ & $\begin{array}{l}\text { Compressive } \\
\text { Strength N/mm }{ }^{2} \\
1 \% \\
\text { polypropylene } \\
\text { fiber }\end{array}$ \\
\hline $\begin{array}{l}\text { Polypropylene } \\
12 \mathrm{~mm} \\
\text { (PP1) }\end{array}$ & 29.52 & 32.4 & 37.6 & 38.78 \\
\hline $\begin{array}{l}\text { Poly propylene } \\
6 \mathrm{~mm} \\
(\mathrm{PP} 2) \\
\end{array}$ & 29.5 & 27.76 & 35.6 & 31.81 \\
\hline $\begin{array}{l}\text { Polypropylene } \\
3 \mathrm{~mm} \\
\text { (PP3) }\end{array}$ & 29.52 & 18.25 & 34.9 & 29.8 \\
\hline
\end{tabular}

Table 5: Results of Split Tensile Strength of poly propy lene reinforced concrete

\begin{tabular}{|l|l|l|l|l|}
\hline Type of PP fiber & $\begin{array}{l}\text { Split Tensile } \\
\mathrm{N} / \mathrm{mm}^{2}\end{array}$ & $\begin{array}{l}\text { Split Tensile } \\
\mathrm{N} / \mathrm{mm}^{2}\end{array}$ & $\begin{array}{l}\text { Split Tensile } \\
\mathrm{N} / \mathrm{mm}^{2}\end{array}$ & $\begin{array}{l}\text { Split Tensile } \\
\mathrm{N} / \mathrm{mm}^{2}\end{array}$ \\
& $\begin{array}{l}0 \% \\
\text { Poly propylene } \\
\text { fiber }\end{array}$ & $\begin{array}{l}0.25 \% \\
\text { Poly propylene } \\
\text { fiber }\end{array}$ & $\begin{array}{l}0.5 \% \\
\text { poly propylene } \\
\text { fiber }\end{array}$ & $\begin{array}{l}\text { poly propylene } \\
\text { fiber }\end{array}$ \\
\hline $\begin{array}{l}\text { Polypropylene } \\
\text { (PP1) }\end{array}$ & 3.02 & 3.27 & 3.9 & 4.18 \\
\hline $\begin{array}{l}\text { Polypropylene } \\
\text { 6 mm } \\
\text { (PP2) }\end{array}$ & 3.02 & 3.21 & 3.8 & 4.19 \\
\hline $\begin{array}{l}\text { Polypropylene } \\
\text { 3mm } \\
\text { (PP3) }\end{array}$ & 2.99 & 2.8 & 3.29 & 3.6 \\
\hline
\end{tabular}

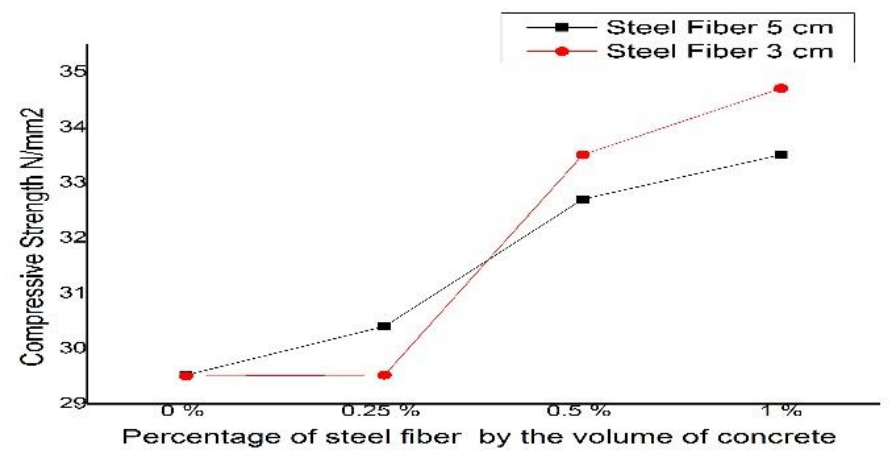

Graph 1: Comparison of compressive strength of steel reinforced concrete at room temperature 


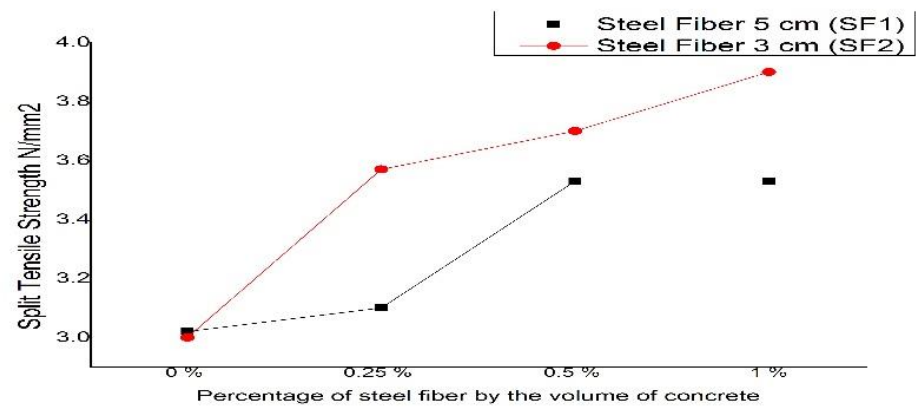

Graph 2 : Comparison of split tensile strength of steel reinforced concrete at room temperature

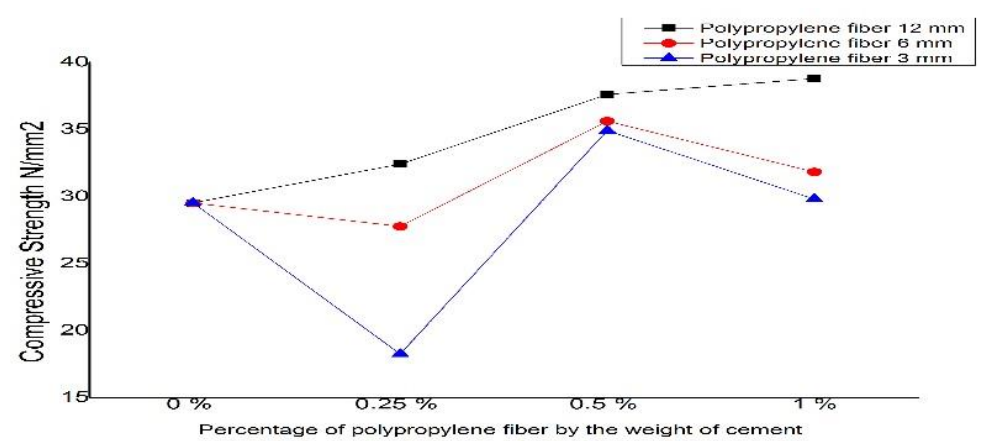

Graph 3 : Comparison of compressive strength of poly propylene reinforced concrete at room temperature

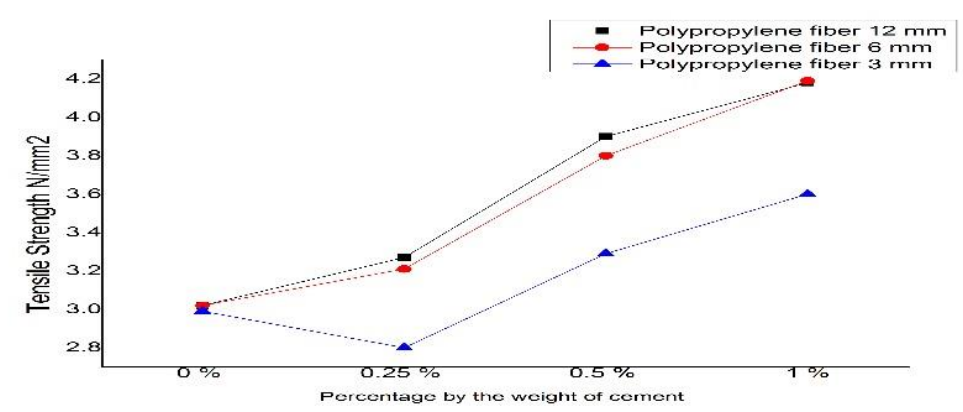

Graph 4: Comparison of split tensile strength of poly propy lene reinforced concrete at room temperature

\section{Conclusion}

1. Among 37 different matrices considered in the present investigation, matrix having $1 \%$ volume fraction of steel fibers $3 \mathrm{~cm}$ and $1 \%$ volume by cement of PP fibers $12 \mathrm{~mm}$ indicated the maximum increases in compressive strength .

2. Whereas matrix having $1 \%$ of steel fibers $3 \mathrm{~cm}$ and $1 \%$ polypropylene $12 \mathrm{~mm}$ had the best performance in split tensile strength. Also ratio $0.5 \%$ poly propylene $6 \mathrm{~mm}$ had shown good results. 
3.Thus the optimum fiber ratio of $1 \%$ by the volume of concrete of steel fiber with $3 \mathrm{~cm}$ length and poly propylene $1 \%$ by the weight of cement of length $12 \mathrm{~mm}$ have shown the best performance and offer potential advantages in improving concrete properties.

\section{References}

1. Saxena J, Saxena A : Enhacement the Strength of Conventional Concrete by using Nylon Fiber (2015) International Journal of Engineering and Science.

2. Seka.S, Kesavan D : Performance of hybrid reinforced concrete under compression and flexure (2015) NBM Construction.

3. Beötzung F, Fairbairn.E, Hoshino, Dickie : Durability of strain hardening fibre reinforced cement based composites (2011) Springer Journal.

4. Sharma.A, Parveen: Structural behavior of fibrous concrete using polypropylene ibres (2013) International Journal of Modern Engineering Research.

5. Usam.A : Materials Development of Steel and Basalt fiber reinforced concretes (2013) Norwegian University of Science and Technology.

6. Ramujee.K : Strength properties of poly propy lene fiber reinforced concrete (2013) International Journal of Innovative Research in Engineering and Technology.

7. Patodi.S.C, Kulkami C.V : Perfomance Evaluation of Hybrid Fiber Reinfoced Concrete Matrix (2013) International Journal of Engineering Research and Applications.

8. Beddar M , Belgara. L : Optimizing of steel fiber reinforced concrete mix desing (2013), Departament of Civil Engineering M.Sila University Algeria.

9. Standard Specification for fiber reinforced concrete and shotcrete, ASTM C1116-91

10. ACI Committee 544, Guide for Specify ing Proportioning, Mixing Placing and Finishing Steel Reinforced Concrete, ACI 544, 3R American Concrete Institute, Farmington Mich

11. ASTM; West Conshohocken, Pa, 1991 A.Balogh : Synthetic Fibers Concrete Construction, July 1992 pp 525-530

12. Ruby S, Geethanjali C : Influence of hybrid fiber on reinforced concrete (2014) International Journal of Advanced Structures and Geotechnical Engineering.

13. Alias M, Nor M, Ariffin J: Perfomance of hybrid steel fibers reinforced concrete subjected to air blast loading 